\title{
EFFECT OF INCUBATION TIME, INOCULUM SIZE, TEMPERATURE, PASTEURIZATION TIME, GOAT MILK POWDER AND WHEY POWDER ON ACE INHIBITORY ACTIVITY IN FERMENTED MILK BY L. PLANTARUM LP69
}

\author{
Guowei Shu ${ }^{\varpi}$, Hui Yang, He Chen, Qiuhong Zhang, Yue Tian \\ College of Life Science and Engineering, Shaanxi University of Science and Technology \\ Xián, 70021, China
}

\begin{abstract}
Background. Angiotensin I converting enzyme (ACE) plays an important physiological role in regulating hypertension. Lactic acid bacteria are known to produce ACE inhibitory peptides which can lower hypertension during fermentation.

Methods. The effect of incubation time $(0 \sim 36 \mathrm{~h})$, inoculum size $(3,4,5,6$ and $7 \%$, v/v), temperature $(25,30$, 35,40 and $\left.45^{\circ} \mathrm{C}\right)$, sterilization time $(5,10,15,20$ and $25 \mathrm{~min})$, concentration of goat milk powder $(8,10,12$, 14 and $16 \%, \mathrm{w} / \mathrm{v})$ and whey powder $(0.5,0.6,0.7,0.8$ and $0.9 \%, \mathrm{w} / \mathrm{v})$ on ACE inhibitory peptides fermented from goat milk by Lactobacillus plantarum LP69 was investigated using single factor experiment.

Results. The optimal incubation time, inoculum size, temperature, pasteurization time, goat milk powder and whey powder in fermented milk by L. plantarum LP69 was $14 \mathrm{~h}, 3.0 \%, 35^{\circ} \mathrm{C}, 20 \mathrm{~min}, 14 \%$ and $0.70 \%$ for ACE inhibitory activity and $22 \mathrm{~h}, 3.0 \%, 40^{\circ} \mathrm{C}, 25 \mathrm{~min}, 16 \%$ and $0.60 \%$ for viable cell counts, respectively. Conclusion. The incubation time, inoculum size, temperature, pasteurization time, goat milk powder and whey powder had a significant influence on ACE inhibitory activity in fermented milk by Lactobacillus plantarum LP69, the results are beneficial for further screening of main factors by using fractional factorial designs.
\end{abstract}

Key words: ACE inhibitory peptide, goat milk, Lactobacillus plantarum, inoculum size, pasteurization time, incubation time, whey powder

\section{INTRODUCTION}

Hypertension is a common disease, which leads to stroke, coronary heart disease, kidney dysfunction, disability and death (López-Fandiño et al., 2006), and it is often accompanied by obesity, hyperlipidemia, arteriosclerosis and coronary heart disease. The angiotensin converting enzyme (ACE, EC. 3.4.15.1) is a peptidyl dipeptide hydrolase and plays an important physiological role in regulating blood pressure
(Leclerc et al., 2002). Therefore, inhibition of ACE activity is considered to be a useful approach in the treatment of hypertension.

Angiotensin converting enzyme inhibitors (ACE-inhibitors) plays an important role in the world of medicine. ACE-inhibitors prolong patients' life with ischemic heart disease, heart failure and impaired left ventricular contractility. Application of ACE inhibitors

『shuguowei@gmail.com 
Shu, G., Yang, H., Chen, H., Zhang, Q., Tian, Y. (2015). Effect of incubation time, inoculum size, temperature, pasteurization time, goat milk powder and whey powder on ACE inhibitory activity in fermented milk by L. plantarum LP69. Acta Sci. Pol. Technol. Aliment., 14(2), 107-116. DOI: 10.17306/J.AFS.2015.2.12

prevents adverse cardiac remodelling infarction after myocardialinfarction. Therefore, it is highly appreciated to research on the isolation and enhancement of its preparation. Studies on bioactive peptides are better planned and thereby, well documented.

Recently, certain functional foods containing ACE inhibitory peptides have been shown to act as an additional or alternative treatment in hypertension. Fermented milks containing many ACE-inhibitory peptides has been produced using different lactic acid bacteria or yeast, such as Lactobacillus helveticus, L. casei, Lactobacillus casei spp. Pseudoplantarum, L. plantarum, L. rhamnosus, L. acidophilus, L. lactis ssp. lactis, L. lactis ssp. Cremoris, Enterococcus faecalis and Clavispora lusitaniae KL4A (Algaron et al., 2004; Ashar and Chand, 2003; Chen et al., 2012; Chaves-López et al., 2012; Fuglsang et al., 2003; Gobbetti et al., 2000; Hernández-Ledesma et al., 2004; Leclerc et al., 2002; Muguerza et al., 2006; Nakamura et al., 1995; Quirós et al., 2007; Robert et al., 2004; Rodríguez-Figueroa et al., 2010; Rokka et al., 1997; Shuang et al., 2008; Vermeirssen et al., 2003; Vishwanath and Purnima, 2014; Yamamoto et al., 1994a, 1994b, 1999), most studies were based on milk as a medium and seldom goat milk was used.

In our previous study, 28 probiotic Lactobacillus strains were used to ferment goat milk to obtain products with high Angiotensin I-converting enzyme inhibitory activity, the results showed that 20 strains had ACE inhibitory activity and among them 4 strains including L. bulgaricus LB6, Lactobacillus reuteri LT33, Lactobacillus rhamnosus LR22 and Lactobacillus plantarum LP69 (which was previously mistaken as Lactobacillus helveticus) were especially significant as producers of ACE-inhibitory peptides (Chen et al., 2012) and investigated carbon source, organic nitrogen source, salts and fermentation conditions on ACE inhibitory activity in fermented goat milk by Lactobacillus bulgaricus LB6 (Shu et al., 2013a, 2013b, 2014). In this study, effect of incubation time, inoculum size, temperature, pasteurization time, concentration of goat milk powder and whey powder on ACE inhibitory activity in fermented milk by Lactobacillus plantarum LP69 were investigated to provide reference for further optimization.

\section{MATERIAL AND METHODS}

\section{Materials and reagents}

Whole goat milk powder was purchased from Shaanxi Redstar Dairy Co., Ltd. (Weinan city, China). Hippuryl-histidyl-leucine (Hip-His-Leu) and ACE (extracted from rabbit lung, lyophilized powder) were bought from Sigma Chemical Co. (St Louis, MO, USA), whey powder (Hilmar 8010 WPC80, USA), was purchased from Xián Luosenbo Technology Co., Ltd. (Xián, China). All chemicals used were of analytical grade unless otherwise specified.

\section{Microorganisms and activation}

A pure culture of Lactobacillus plantarum LP69, isolated from inner yogurt and identified by $16 \mathrm{~S}$ rDNA, was obtained from the College of Life Science and Engineering, Shaanxi University of Science and Technology. Stock cultures were stored at $-20^{\circ} \mathrm{C}$ in freeze-dried powder prepared from $0.2 \mathrm{ml}$ MRS broth containing Lactobacillus plantarum LP69 and $0.2 \mathrm{ml}$ $20 \%$ reconstituted skimmed milk by freeze-drying. The microorganism was activated successively three times in rehydrated de Mann Rogosa Sharpe (MRS) broth (Haibo media, Qindao, China) at $37^{\circ} \mathrm{C}$ for $24 \mathrm{~h}$ prior to use.

\section{Preparation of fermented goat milk}

$125 \mathrm{~g}$ whole goat milk powder was added to water and attained $1000 \mathrm{ml}$ reconstituted goat milk, then divided equally into 50 anaerobic tubes and pasteurized, inoculated with Lactobacillus plantarum LP69, and fermented at $37^{\circ} \mathrm{C}$ until coagulated, all fermentations were carried out by triplicate. The whey was collected by centrifugation at $5000 \mathrm{~g}$ for $15 \mathrm{~min}$. The viable counts of L. plantarum LP69 in the fermented milk were counted using de Man, Rogosa, Sharpe (MRS) agar (Haibo media, Qindao, China).

\section{Measurement of ACE inhibitory activity}

ACE inhibitory activity was measured by a spectrophotometric assay according to the method of Cushman and Cheung (1971) with some modifications. Added $80 \mu \mathrm{L}$ of each sample to $200 \mu \mathrm{L}$ sodium borate buffer $(0.1 \mathrm{~mol} / \mathrm{L}, \mathrm{pH} 8.3)$ containing $\mathrm{NaCl}(0.30$ $\mathrm{mol} / \mathrm{L})$ and HHL $(5 \mathrm{mmol} / \mathrm{L})$. Then, ACE $(20 \mu \mathrm{L}$, $0.1 \mathrm{U} / \mathrm{mL}$ ) was added and the reaction mixture was 
Shu, G., Yang, H., Chen, H., Zhang, Q., Tian, Y. (2015). Effect of incubation time, inoculum size, temperature, pasteurization time, goat milk powder and whey powder on ACE inhibitory activity in fermented milk by L. plantarum LP69. Acta Sci. Pol. Technol. Aliment., 14(2), 107-116. DOI: 10.17306/J.AFS.2015.2.12

incubated at $37^{\circ} \mathrm{C}$ for $30 \mathrm{~min}$. The reaction was terminated by adding $250 \mu \mathrm{L} 1 \mathrm{~mol} / \mathrm{L} \mathrm{HCl}$. Adding $1.7 \mathrm{~mL}$ ethyl acetate to extract the hippuric acid formed and evaporated at $120^{\circ} \mathrm{C}$ for $30 \mathrm{~min}$, redissolved it in $2 \mathrm{~mL}$ deionized water after cooled at room temperature, then the absorbance was measured at an optical density of $228 \mathrm{~nm}\left(\mathrm{OD}_{280}\right)$. The activity of each sample was measured in triplicate. The ACE inhibitory rate was calculated using the following formula: ACE inhibition $(\%)=(\mathrm{A}-\mathrm{B}) /(\mathrm{A}-\mathrm{C}) \times 100 \%$, where $\mathrm{A}$ is the optical density without the whey fraction, $\mathrm{B}$ is the optical density without $\mathrm{ACE}$ and $\mathrm{C}$ is the optical density in the presence of both ACE and the whey fraction.

\section{Determination of viable cell counts, $\mathrm{pH}$ and titration acidity in the fermented goat milk} The viable cell counts of $L$. plantarum LP69 were determined by using the pour plate technique (Donkor et al., 2006), $1 \mathrm{ml}$ of each fermented goat milk sample was added to $9 \mathrm{ml}$ of saline water $(0.9 \%$, w $/ \mathrm{v}$, $\mathrm{NaCl}$ ) containing $0.1 \mathrm{~g} / \mathrm{L}$ peptone and water diluent followed by vortexing using autovortex mixer for $30 \mathrm{~s}$. The resulting suspension was serially diluted in sterile $0.15 \%(\mathrm{v} / \mathrm{v})$ peptone water (Oxoid) and $1 \mathrm{~mL}$ of the appropriate dilution was used for enumeration by the pour plate technique with MRS agar (Haibo media, Qindao, China) for $48-72 \mathrm{~h}$ at $37^{\circ} \mathrm{C}$. All dilutions were plated in triplicate and results were expressed as colony forming units per milliliter $(\mathrm{CFU} / \mathrm{ml})$ of fermented milk (Chen et al., 2013). The $\mathrm{pH}$ in fermented goat milk was directly evaluated through a $\mathrm{pH}$-meter (pHS-3C) at the room temperature and titration acidity was determined according to the sodium hydroxide titration method and Jill Nieer degrees $\left({ }^{\circ} \mathrm{T}\right)$ described, respectively.

\section{RESULTS AND DISCUSSION}

\section{Effect of incubation time on ACE inhibitory activity in fermentated goat milk}

The activated L. plantarum LP69 at inoculum size 5\% was transferred into $14 \%$ pasteurized reconstituted goat milk and cultured at $37^{\circ} \mathrm{C}$ for $36 \mathrm{~h}$. The samples were taken out for determining ACE inhibition, viable cell counts, $\mathrm{pH}$ and titration acidity every $2 \mathrm{~h}$ for $0 \sim 24 \mathrm{~h}$ and every $3 \mathrm{~h}$ for $24 \sim 36 \mathrm{~h}$. The results were shown in Figure 1.

The growth curve of L. plantarum LP69 showed as "S" type, $0-2 \mathrm{~h}$ was a period of adjustment, the viable count of L. plantarum LP69 was $8.49 \times 10^{6} \mathrm{CFU} / \mathrm{mL}$

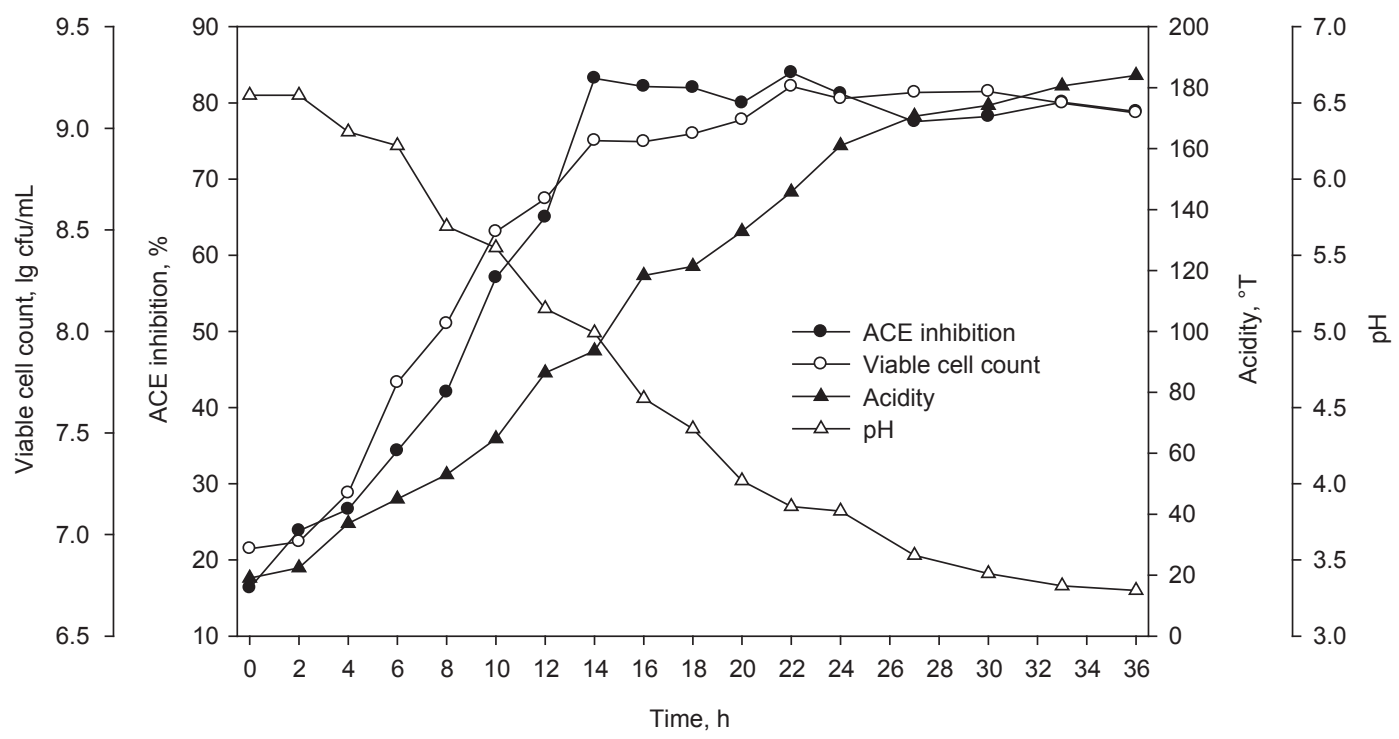

Fig. 1. Effect of incubation time on ACE inhibition, viable cell counts, $\mathrm{pH}$ and titration acidity in fermented goat milk 
Shu, G., Yang, H., Chen, H., Zhang, Q., Tian, Y. (2015). Effect of incubation time, inoculum size, temperature, pasteurization time, goat milk powder and whey powder on ACE inhibitory activity in fermented milk by L. plantarum LP69. Acta Sci. Pol. Technol. Aliment., 14(2), 107-116. DOI: 10.17306/J.AFS.2015.2.12

after introducing into milk and slowly increased, $\mathrm{pH}$ value decreased and the titration acidity increased slowly; $2-14 \mathrm{~h}$ was logarithmic phase for cell growth of $L$. plantarum $L P 69$, the numbers of viable counts increased rapidly, changes of $\mathrm{pH}$ and acidity is large, when the $\mathrm{pH}$ value decreased to 4.6-5.0, the fermented milk began to appear curd; then $L$. plantarum LP69 grew into the stable phase from $14 \mathrm{~h}$. The viable count remained almost unchanged because the growth rate and death rate of L. plantarum LP69 is basically the same, the value of $\mathrm{pH}$ continues to decline and titration acidity continued to increase, but the trend tended to be smooth. During the $36 \mathrm{~h}$ fermentation, the ACE inhibition in fermented goat milk increased rapidly in $0-14 \mathrm{~h}$, tended to be smooth in 14-18 $\mathrm{h}$, then decreased gradually from the beginning of $18 \mathrm{~h}$, which was consistent with the growth regularity of $L$. plantarum $L P 69$. The ACE inhibition increased with the increase in the number of live bacteria in the first $14 \mathrm{~h}$ when L. plantarum LP69 was in logarithmic phase, the possible reasons was that the ACE inhibitory peptide content reached the maximum for the hydrolysis of goat milk protein by proteases or peptidase produced by L. plantarum LP69, but the proteases or peptidase was inhibited or the
ACE inhibitory peptide was broken down when the titration acidity increased after $14 \mathrm{~h}$, which led to ACE inhibition decrease. The ACE inhibition in fermented goat milk had no significant differences during 14 $22 \mathrm{~h}$. The ACE inhibitions, the viable count, $\mathrm{pH}$ and titration acidity in fermented goat milk by L. plantarum LP69 was $83.21 \%, 8.7 \times 10^{8} \mathrm{CFU} / \mathrm{ml}$, 4.99 and $93.6^{\circ} \mathrm{T}$, but The ACE inhibition in fermented goat milk by $L$. bulgaricus $L B 6$ reached maximum $(74.70 \%)$ at $12 \mathrm{~h}$ and the viable count, $\mathrm{pH}$ and titration acidity was $3.72 \times 10^{7} \mathrm{CFU} / \mathrm{mL}, 4.44$ and $149.8^{\circ} \mathrm{T}$ (Shu et al., 2014), which showed L. plantarum LP69 had higher ACE inhibition, grew faster but produced less lactic acid than L. bulgaricus LB6. Therefore, the incubation time was chosen as $14 \mathrm{~h}$ for further research on ACE inhibitory peptide produced by L. plantarum LP69, but the optimal incubation time for L. bulgaricus $L B 6$ was $12 \mathrm{~h}$ (Shu et al., 2014).

\section{Effect of inoculum size on ACE inhibitory activity in fermentated goat milk}

The L. plantarum LP69 was inoculated into the $14 \%$ pasteurized reconstituted goat milk at different inoculum size $(3,4,5,6$ and $7 \%)$, respectively. The results were shown in Figure 2.

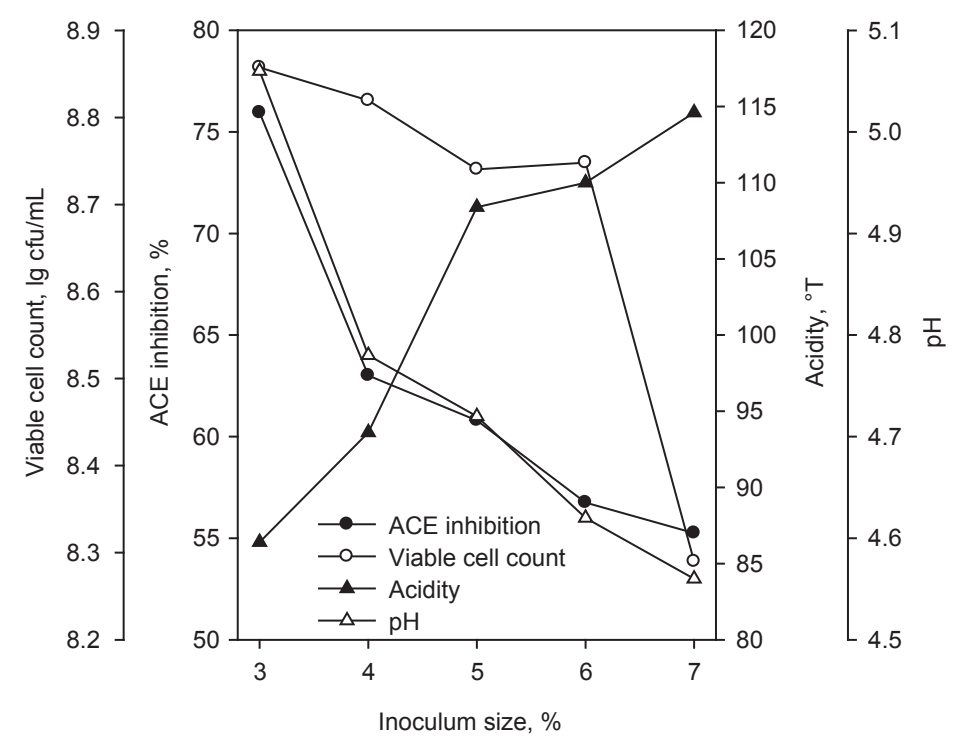

Fig. 2. Effect of inoculum size on ACE inhibition, viable cell counts, $\mathrm{pH}$ and titration acidity in fermented goat milk 
Shu, G., Yang, H., Chen, H., Zhang, Q., Tian, Y. (2015). Effect of incubation time, inoculum size, temperature, pasteurization time, goat milk powder and whey powder on ACE inhibitory activity in fermented milk by L. plantarum LP69. Acta Sci. Pol. Technol. Aliment., 14(2), 107-116. DOI: 10.17306/J.AFS.2015.2.12

As shown in Figure 2, both the viable cell counts of L. plantarum LP69 and the ACE inhibition in fermented goat milk decreased with the inoculum size increasing. The viable cell counts of $L$. plantarum LP69 in fermented goat milk decreased from $7.2 \times 10^{8}$ $\mathrm{CFU} / \mathrm{ml}$ at $3 \%$ inoculum size to $1.95 \times 10^{8} \mathrm{CFU} / \mathrm{ml}$ at $7 \%$ inoculum size, and the ACE inhibition decreased from $75.95 \%$ at $3 \%$ inoculum size to $55.25 \%$ at $7 \%$ inoculum size. This may be due to the gradual increase of viable cells of $L$. plantarum $L P 69$, the nutrients in reconstituted goat milk were not meet the growth need of $L$. plantarum LP69, which led to goat milk protein and peptides were hydrolysed by proteolytic enzyme in L. plantarum LP69 to smaller peptide fragments or even a single amino acid to meet their growth, and some amino acid residues with ACE inhibitory peptides may have also been decomposed and led to reduction of ACE inhibition in fermented goat milk. The $\mathrm{pH}$ decreased and titration acidity increased in fermented goat milk with the increase of the inoculum size, the titration acidity and $\mathrm{pH}$ showed the opposite trend, titratable acidity and inoculum size was positive correlation, while the $\mathrm{pH}$ value was negatively correlated with the inoculum size. The optimal inoculum size was 3\% for ACE inhibition and the viable cell count of $L$. plantarum LP69, the result was same as Liang Mei-yan and Chen Qing-sen (2009), who used Lactobacillus helveticus TS6024 to ferment cow milk, but the optimal inoculum size was 5\% for ACE inhibition in fermented goat milk by L. bulgaricus LB6 (Shu et al., 2013a, 2013b). The effect of inoculum size has different terms than incubation time with a large difference in $\mathrm{pH}$ from Figure 1 and 2, below 4.6 when tested inoculum size and incubation time at $\mathrm{pH}$ tested about 3 .

\section{Effect of temperature on ACE inhibitory activity in fermentated goat milk}

The L. plantarum LP69 was inoculated into the $14 \%$ pasteurized reconstituted goat milk at 5\% inoculum size and cultured at different temperature $(25,30,35$, 40 and $45^{\circ} \mathrm{C}$ ) for $12 \mathrm{~h}$, respectively. The results were shown in Figure 3.

As shown in Figure 3, the ACE inhibition and viable counts of L. plantarum LP69 in fermented goat milk first increased and then decreased with the incubation temperature increasing. The ACE inhibition increased from $31.75 \%$ at $25^{\circ} \mathrm{C}$ to $81.25 \%$ at $35^{\circ} \mathrm{C}$, then decreased to $30.00 \%$ at $45^{\circ} \mathrm{C}$, the viable counts of L. plantarum LP69 increased from $2.15 \times 10^{8} \mathrm{CFU} / \mathrm{ml}$

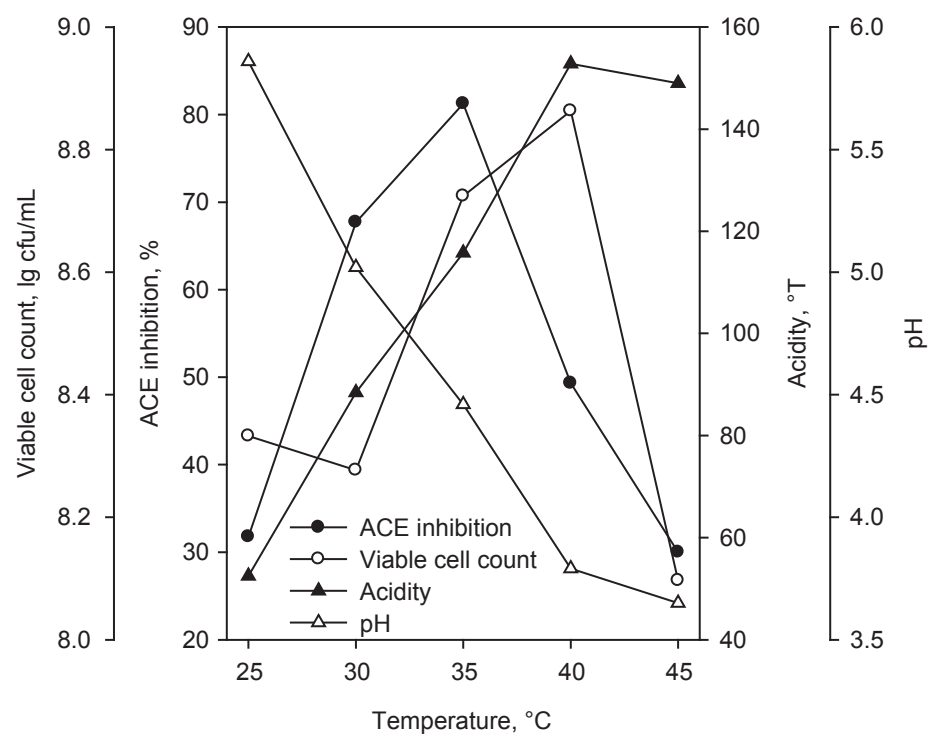

Fig. 3. Effect of temperature on ACE inhibition, viable cell counts, $\mathrm{pH}$ and titration acidity in fermented goat milk 
at $25^{\circ} \mathrm{C}$ to $7.30 \times 10^{8} \mathrm{CFU} / \mathrm{ml}$ at $40^{\circ} \mathrm{C}$, then decreased to $1.25 \times 10^{8} \mathrm{CFU} / \mathrm{ml}$ at $45^{\circ} \mathrm{C}$. The temperature had a significant effect on the growth of $L$. plantarum LP69 and activity of proteolytic enzyme. When the temperature was low, the metabolic activity of L. plantarum LP69 was weak, grew slowly and enzyme activity was not strong, which led to low ACE inhibition and viable counts of L. plantarum LP69; with temperature increasing, L. plantarum LP69 quickly grew and the enzyme activity increased gradually, which led to increase ACE inhibition and viable counts of $L$. plantarum $L P 69$, the viable counts of $L$. plantarum $L P 69$ reached the maximum number at the optimum temperature, the ACE inhibition reached highest when protease enzyme activity was at optimum temperature; when temperature continued to rise beyond the optimal range, the enzymes in L. plantarum LP69 were inhibited or destroyed, either cell growth or protease hydrolysis were subject to a certain degree of inhibition. So the optimal temperature for ACE inhibition and the viable cell counts of $L$. plantarum LP69 were $35^{\circ} \mathrm{C}$ and $40^{\circ} \mathrm{C}$, respectively.

The $\mathrm{pH}$ gradually decreased, titration acidity first increased and decreased with the increase of temperature from Figure 3, the incubation temperature on $\mathrm{pH}$ and titration acidity in fermented goat milk by L. plantarum LP69 had significant difference ( $p<$ $0.05)$. The $\mathrm{pH}$ decreased from 5.86 at $25^{\circ} \mathrm{C}$ to 3.79 at $45^{\circ} \mathrm{C}$. The titration acidity gradually increased from $52.50^{\circ} \mathrm{T}$ at $25^{\circ} \mathrm{C}$ to $152.80^{\circ} \mathrm{T}$ at $40^{\circ} \mathrm{C}$ then decreased to $149.00^{\circ} \mathrm{T}$, but the viable counts of $L$. plantarum $L P 69$ was $1.25 \times 10^{8} \mathrm{CFU} / \mathrm{ml}$ at $45^{\circ} \mathrm{C}$. The reason was maybe L. plantarum LP69 grew faster at hign tempetature and produced more lactic acid, which led to lower $\mathrm{pH}$ value, but $L$. plantarum LP69 gradually died with the extension of incubation time. The result showed that incubation temperature could promote production of lactic acid by L. plantarum LP69.

\section{Effect of pasteurization time on ACE inhibitory activity in fermentated goat milk}

The $14 \%$ reconstituted goat milk was pasteurized at $90^{\circ} \mathrm{C}$ for different time $(5,10,15,20$ and $25 \mathrm{~min}$, respectively). The results were shown in Figure 4.

As shown in Figure 4, the ACE inhibition in fermented goat milk first increased and then decreased, the viable counts of L. plantarum LP69 increased, but the $\mathrm{pH}$ and acidity had no significant difference in fermented goat milk with the pasteurization time increasing. The ACE inhibition increased from $44.00 \%$

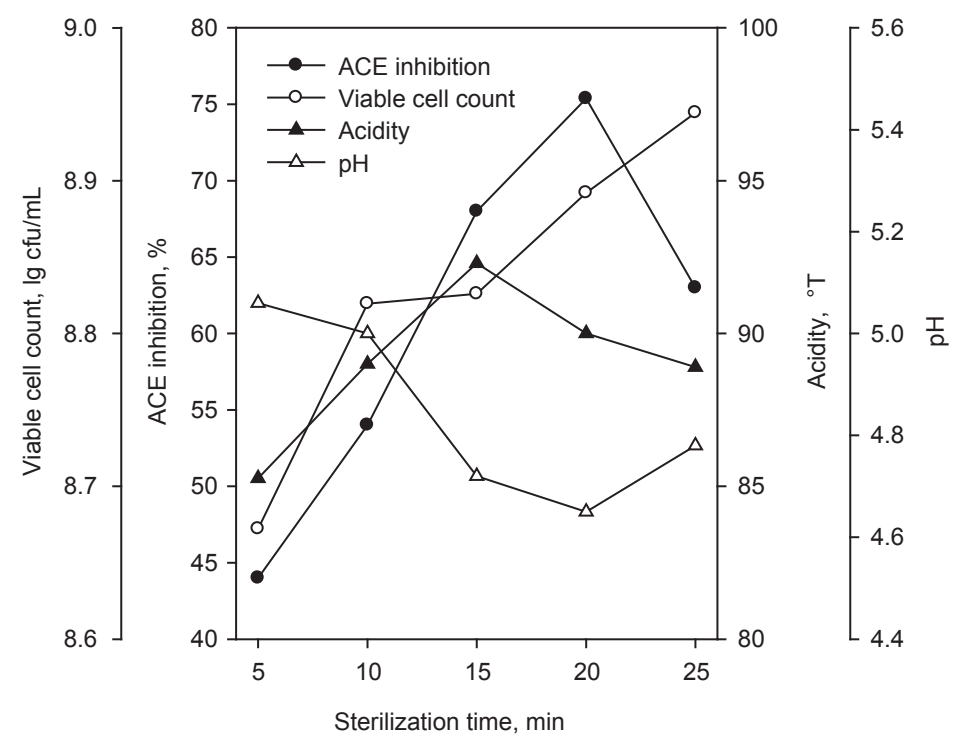

Fig. 4. Effect of pasteurization time on ACE inhibition, viable cell counts, $\mathrm{pH}$ and titration acidity in fermented goat milk 
Shu, G., Yang, H., Chen, H., Zhang, Q., Tian, Y. (2015). Effect of incubation time, inoculum size, temperature, pasteurization time, goat milk powder and whey powder on ACE inhibitory activity in fermented milk by L. plantarum LP69. Acta Sci. Pol. Technol. Aliment., 14(2), 107-116. DOI: 10.17306/J.AFS.2015.2.12

at 5 min sterilization time to $75.38 \%$ at 20 min pasteurization time, then decreased to $63.00 \%$ at $25 \mathrm{~min}$, the viable counts of L. plantarum LP69 increased from $4.70 \times 10^{8} \mathrm{CFU} / \mathrm{ml}$ at $5 \mathrm{~min}$ sterilization time to $8.80 \times 10^{8} \mathrm{CFU} / \mathrm{ml}$ at $25 \mathrm{~min}$ sterilization time, which indicated the pasteurization time had a significant effect on the growth of $L$. plantarum LP69 and denaturing of protein in goat milk. The protein in goat milk denatured during pasteurization process, and the partly denatured protein was beneficial for the use of $L$. plantarum LP69, but it would effect the growth of L. plantarum LP69 when the pasteurization time was too long, which led to excessive protein denaturation, so the optimal sterilizing time for ACE inhibition and the viable cell counts of $L$. plantarum LP69 were $20 \mathrm{~min}$ and $25 \mathrm{~min}$, respectively, but the optimal pasteurization time for ACE inhibition was $30 \mathrm{~min}$ for cow milk fermented by Lactobacillus helveticus TS6024 (Liang and Chen, 2009).

\section{Effect of whole goat milk powder on ACE inhibitory activity in fermentated goat milk}

The whole goat milk powder was mixed with distilled water and the concentrations of reconstituted goat milk were $8 \%, 10 \%, 12 \%, 14 \%$ and $16 \%$, respectively.
After pasteurization and cooling to $37^{\circ} \mathrm{C}$, L. plantarum $L P 69$ was inoculated and cultured at $37^{\circ} \mathrm{C}$ for $14 \mathrm{~h}$, the results were shown in Figure 5.

As shown in Figure 5, the viable cell counts of L. plantarum LP69 in fermented goat milk increased, but the ACE inhibition in fermented goat milk first increased and then decreased with the concentrations of goat milk powder increasing. The viable cell counts of L. plantarum LP69 in fermented goat milk increased from $5.10 \times 10^{8} \mathrm{CFU} / \mathrm{ml}$ at $8 \%$ goat milk powder to $1.60 \times 10^{9} \mathrm{CFU} / \mathrm{ml}$ at $16 \%$ goat milk powder, but the ACE inhibition increased from $43.30 \%$ at $8 \%$ goat milk powder to $74.98 \%$ at $14 \%$ goat milk powder, then decreased to $58.76 \%$ at $16 \%$ goat milk powder, which indicated goat milk powder in the concentration of $10-14 \%$ can promote the increase of ACE inhibition, but goat milk powder in concentrations of $14-16 \%$ will inhibit production of ACE inhibitory peptide, the reason for that may be due to increase protein with the concentration goat milk powder from $10 \%$ to $14 \%$ and increase available substrate for enzymatic hydrolysis and promote production of ACE inhibitory peptide. With concentration of goat milk powder continued to increase and led to excessive protein inhibit production of proteolytic

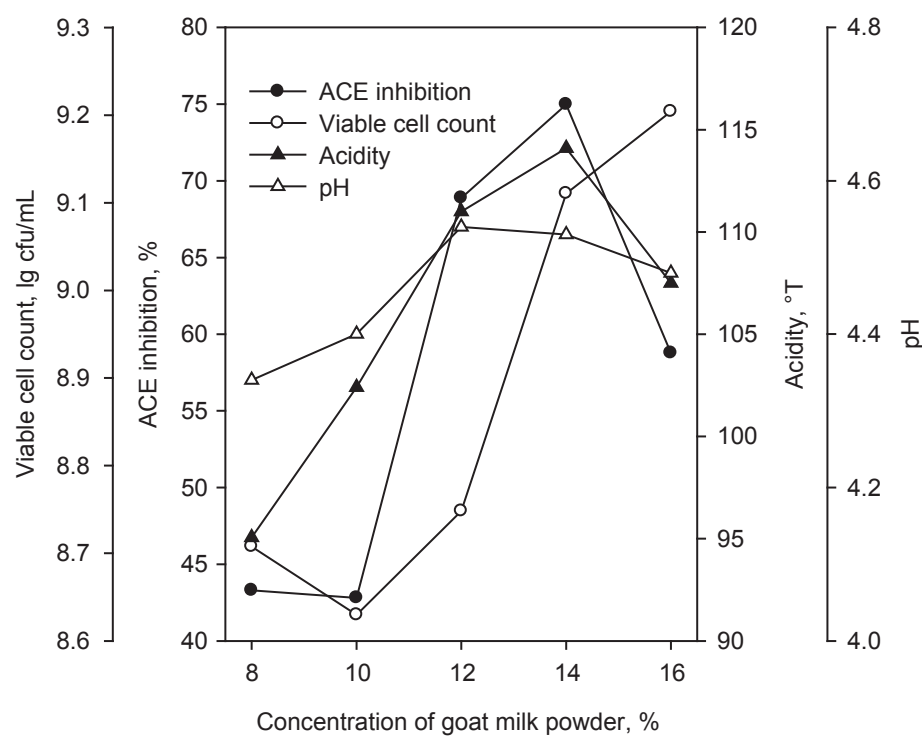

Fig. 5. Effect of concentration of goat milk powder on ACE inhibition, viable cell counts, $\mathrm{pH}$ and titration acidity in fermented goat milk 
enzymes, thereby caused a reduction in ACE inhibitory peptide and led to a decline in the rate of ACE inhibition. Zhang showed that the concentration of bovine milk powder would affect the proteolytic activity and ACE inhibition of Lactobacillus casei $D 400$ and the ACE inhibition in fermented bovine milk first increased and then decreased with the concentrations of bovine milk powder increasing, the optimal concentrations of bovine milk powder was $12 \%$ and the optimal concentrations of goat milk powder for ACE inhibition in the study was $14 \%$, which was the same as in our previous study (Shu et al., 2013a, 2013b). The $\mathrm{pH}$ change had no significant difference $(p<0.05)$ and titration acidity first increased with the increase of the concentration of goat milk powder from Figure 5. The titration acidity gradually increased from $95.06^{\circ} \mathrm{T}$ at $8 \%$ goat milk powder to $114.1^{\circ} \mathrm{T}$ at $16 \%$ goat milk powder, then decreased to $107.50^{\circ} \mathrm{T}$.

\section{Effect of whey powder on ACE inhibitory activity in fermentated goat milk}

The whey powder was added to pasteurized reconstituted goat milk and the concentration was $0.50,0.60$, $0.70,0.80$ and $0.90 \%$, respectively. The inoculum size was $5 \%$ and cultured at $37^{\circ} \mathrm{C}$ for $14 \mathrm{~h}$, the results were shown in Figure 6.

As shown in Figure 6, the viable counts and ACE inhibition in fermented goat milk first increased and then decreased with the concentration of whey powder increasing, the viable counts reached maximum value $\left(6.50 \times 10^{8} \mathrm{CFU} / \mathrm{mL}\right)$ at whey powder $0.60 \%$, but ACE inhibition reached maximum value $(84.27 \%)$ at whey powder $0.70 \%$. The ACE inhibition gradually decreased in the cow milk fermented by Lactobacillus case $i$ with the concentration of whey powder increasing (Jiang et al., 2011), which may be because the structure and content of whey protein in bovine and goat milk is different. The variation between $\mathrm{pH}$ and titration acidity had an opposite trend with the increase of the concentration of whey powder from Figure 6 . The titration acidity first increased from $88.0^{\circ} \mathrm{T}$ at $0.50 \%$ whey powder to $93.5^{\circ} \mathrm{T}$ at $0.70 \%$ whey powder, then decreased to $83.0^{\circ} \mathrm{T}$ at $0.90 \%$ whey powder, but the $\mathrm{pH}$ decreased from 4.81 at $0.50 \%$ whey powder to 4.72 at $0.70 \%$ whey powder, then increased to 4.98 at $0.90 \%$ whey powder, which suggested that adding whey powder had no significant effect on acidity and $\mathrm{pH}$ in fermented goat milk. The optimal concentration of whey powder for ACE

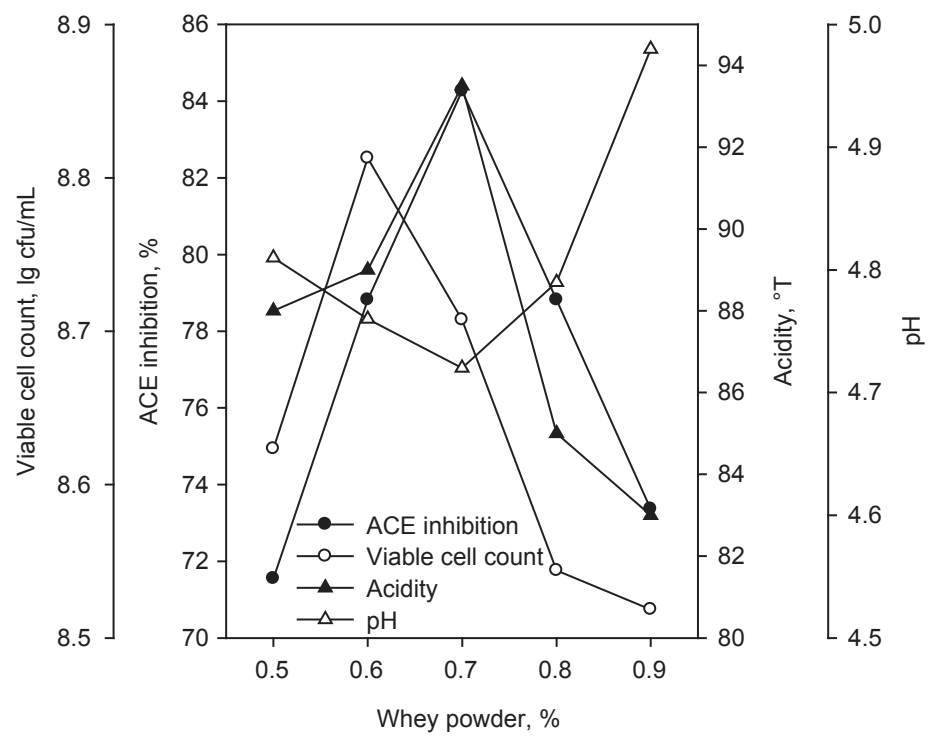

Fig. 6. Effect of concentration of whey powder on ACE inhibition, viable cell counts, $\mathrm{pH}$ and titration acidity in fermented goat milk 
Shu, G., Yang, H., Chen, H., Zhang, Q., Tian, Y. (2015). Effect of incubation time, inoculum size, temperature, pasteurization time, goat milk powder and whey powder on ACE inhibitory activity in fermented milk by L. plantarum LP69. Acta Sci. Pol. Technol. Aliment., 14(2), 107-116. DOI: 10.17306/J.AFS.2015.2.12

inhibition and the viable cell counts of $L$. plantarum $L P 69$ were $0.70 \%$ and $0.60 \%$, respectively, which was in agreement with our previous study (Shu et al., 2014).

\section{CONCLUSION}

The optimal incubation time, inoculum size, temperature, pasteurization time, goat milk powder and whey powder in fermented milk by L. plantarum LP69 was $14 \mathrm{~h}, 3.0 \%, 35^{\circ} \mathrm{C}, 20 \mathrm{~min}, 14 \%$ and $0.70 \%$ for $\mathrm{ACE}$ inhibitory activity and $22 \mathrm{~h}, 3.0 \%, 40^{\circ} \mathrm{C}, 25 \mathrm{~min}, 16 \%$ and $0.60 \%$ for viable cell counts, respectively. The ACE inhibitory activity and viable cell counts reached $74.70 \%$ and $1.61 \times 10^{9} \mathrm{CFU} / \mathrm{ml}, 75.95 \%$ and $7.2 \times 10^{8}$ $\mathrm{CFU} / \mathrm{ml}, 81.25 \%$ and $7.30 \times 10^{8} \mathrm{CFU} / \mathrm{ml}, 75.38 \%$ and $8.8 \times 10^{8} \mathrm{CFU} / \mathrm{ml}, 74.98 \%$ and $1.60 \times 10^{9} \mathrm{CFU} / \mathrm{ml}$, $84.27 \%$ and $6.50 \times 10^{8} \mathrm{CFU} / \mathrm{ml}$ under optimal condition mentioned above.

\section{ACKNOWLEDGMENT}

The project was partly supported by the Science and Technology Research Development plan project of Shaanxi Province (No. 2014K01-17-07), Shaanxi Provincial Education Department (No. 2013JK0747) and the science and technology plan project of Xián city (No. NC1317 (1)), Shaanxi province, China.

\section{REFERENCES}

Algaron, F., Miranda, G., Le Bars, D., Monnet, V. (2004). Milk fermentation by Lactococcus lactis with modified proteolytic systems to accumulate potentially bio-active peptides. Lait, 84, 115-123.

Ashar, M. N., Chand, R. (2003). ACE-inhibitory activity of lactic acid bacteria in fermented milks. Milchwissenschaft, 58, 59-61.

Chaves-López, C., Tofalo, L., Serio, A., Paparella, A., Sacchetti, G., Suzzi, G. (2012). Yeasts from Colombian kumis as source of peptides with angiotensin I converting enzyme (ACE) inhibitory activity in milk. Int. J. Food Microbiol., 159, 39-46.

Chen, H., Wang, J., Luo, Q., Shu, G. (2013). Effect of NaH$\mathrm{CO}_{3}, \mathrm{MgSO}_{4}$, sodium Ascorbate, sodium glutamate, phosphate buffer on survival of Lactobacillus bulgaricus during freeze-drying. Adv. J. Food Sci. Techn., 5, $771-774$.
Chen, H., Ji, Z., Shu, G., Xing, H. (2012). Effect of Probiotic Lactobacillus Strains on Angiotensin I converting enzyme inhibitory activity from fermented goat milk. Adv. Mat. Res. 531, 442-445.

Cushman, D. W., Cheung, H. S. (1971). Spectrophotometric assay and properties of the angiotensin I - converting enzyme of rabbit lung. Biochem. Pharmacol. 20, 1637-1648.

Donkor, O. N., Henriksson, A., Vasiljevic, T., Shah, N. P. (2006). Effect of acidification on the activity of probiotics in yoghurt during cold storage. Int. Dairy J., 16, 1181-1189.

Fuglsang, A., Rattray, F., Nilsson, D., Nyborg, N. C. B. (2003). Lactic acid bacteria: inhibition of angiotensin converting enzyme in vitro and in vivo. Antonie van Leeuwenhoek, 83, 27-34.

Gobbetti, M., Ferranti, P., Smacchi, E., Goffredi, F., Addeo, F. (2000). Production of angiotensin-I-converting-enzyme-inhibitory peptides in fermented milks started by Lactobacillus delbrueckii subsp. bulgaricus SS1 and Lactococcus lactis subsp. cremoris FT4. Appl. Environ. Microbiol., 66, 3898-3904.

Hernández-Ledesma, B., Amigo, L., Ramos, M., Recio, I. (2004). Angiotensin converting enzyme inhibitory activity in commercial fermented products. Formation of peptidesunder simulated gastrointestinal digestion. J. Agric. Food Chem., 52, 1504-1510.

Jiang, Z., Wu, G., Huo, G., Tian, B. (2011). Study on external conditions of angiotensin converting enzyme inhibitory peptide derived from fermented milk. Sci. Techn. Food Ind., 32, 106-108.

Leclerc, P.-L., Gauthier, S., Bachelard, H., Santure, M., Roy, D. (2002). Antiypertensive activity of casein-enriched milk fermented by Lactobacillus helvetius. Int. Dairy J., 12 (12), 995-1004.

Liang, M., Chen, Q. (2009). Optimization of fermentation conditions of Lactobacillus helveticus for producing milk-derived ACE inhibitory peptides. Food Sci., 31, 155-160.

López-Fandiño, R., Otte, J., Capm, J. van. (2006). Physiological, chemical and technological aspects of milk-protein-derived peptides with antihypertensive and ACE-inhibitory activity. Int. Dairy J., 16 (11), 1227-1293.

Muguerza, B., Ramos, M., Sánchez, E., Manso, M. A., Miguel, M., Aleixandre, A., Delgado, M. A., Recio, I. (2006). Antihypertensive activity of milk fermented by Enterococcus faecalis strains isolated from raw milk. Int. Dairy J., 16, 61-69.

Nakamura, Y., Yamamoto, N., Sakai, K., Okubo, A., Yamazaki, S., Takano, T. (1995). Purification and 
Shu, G., Yang, H., Chen, H., Zhang, Q., Tian, Y. (2015). Effect of incubation time, inoculum size, temperature, pasteurization time, goat milk powder and whey powder on ACE inhibitory activity in fermented milk by L. plantarum LP69. Acta Sci. Pol. Technol. Aliment., 14(2), 107-116. DOI: 10.17306/J.AFS.2015.2.12

characterization of angiotensin I-converting enzyme inhibitors from sour milk. J. Dairy Sci., 78, 777-783.

Quirós, A., Ramos, M., Muguerza, B., Delgado, M. A., Miguel, M., Aleixandre, A., Recio, I. (2007). Identification of novel antihypertensive peptides in milk fermented with Enterococus faecalis. Int. Dairy J., 17, 33-41.

Robert, M. C., Razaname, A., Mutter, M., Juillerat, M. A. (2004). Peptides derived from sodium caseinate hydrolysates produced by Lactobacillus helveticus NCC 2765. J. Agric. Food Chem., 52, 6923-6931.

Rodríguez-Figueroa, J. C., Reyes-Díaz, R., González-Córdova, A. F., Troncoso-Rojas, R., Vargas-Arispuro, I., Vallejo-Cordoba, B. (2010). Angiotensin-converting enzyme inhibitory activity of milk fermented by wild and industrial Lactococcus lactis strains. J. Dairy Sci., 93, 5032-5038.

Rokka, T., Syvaoja E. L., Tuominen J., Korhonen H. (1997). Release of bioactive peptides by enzymatic proteolysis of lactobacillus GG fermented UHT milk. Milchwiss. Milk Sci. Int., 52, 675-678.

Shu, G., Yang, H., Chen, H., Ji, Z., Xing, H. (2013a). Effect of ascorbic acid, incubation temperature and inoculum size on ACE inhibitory activity in fermented goat milk by Lactobacillus bulgaricus LB6. J. Chem. Pharm. Res., 5 (12), 988-995.

Shu, G., Yang, H., Chen, H., Ji, Z., Xing, H. (2013b). Effect of carbon source and salts on Angiotensin I converting enzyme (ACE) inhibitory activity in fermented goat milk by Lactobacillus bulgaricus LB6. J. Pure Appl. Microbiol., 7 (Spl. Edn.), 301-308.
Shu, G., Yang, H., Chen, H., Ji, Z., Xing, H. (2014). Effect of organic nitrogen source on angiotensin I converting enzyme (ACE) inhibitory peptides fermented by Lactobacillus bulgaricus LB6 from goat milk. Adv. J. Food Sci. Techn., 6 (2), 221-227.

Shuang, Q., Tsuda, H., Miyamoto, T. (2008). Angiotensin I-converting enzyme inhibitory peptides in skim milk fermented with Lactobacillus helveticus $130 B 4$ from camel milk in inner Mongolia, China. J. Sci. Food Agric., 88, 2688-2692.

Vermeirssen, V., Van, J., Decroos, K., Wijmelbeke, L., Verstraete, W. (2003). The impact of fermentation and in vitro digestion on the formation of angiotensin-I-converting enzyme inhibitory activity from pea and whey protein. J. Dairy Sci., 86, 429-438.

Vishwanath, S. V., Purnima, K. T. (2014). Antihypertensive peptides derived from soy protein by fermentation. Int. J. Pept. Res. Ther., 20, 161-168.

Yamamoto, N., Akino, A., Takano, T. (1994a). Antihypertensive effects of different kinds of fermented milk in spontaneously hypertensive rats. Biosci. Biotechn. Biochem., 58, 776-778.

Yamamoto, N., Akino, A., Takano, T. (1994b). Antihypertensive effect of the peptides derived from casein by an extracellular proteinase from Lactobacillus helveticus CP790. J. Dairy Sci., 77, 917-922.

Yamamoto, N., Maeno, M., Takano, T. (1999). Purification and characterization of an antihypertensive peptide from a yoghurt-like product fermented by Lactobacillus helveticus CPN4. J. Dairy Sci., 82, 1388-1393.

Accepted for print - Zaakceptowano do druku: 12.02.2015

Received - Przyjęto: 1.09.2014

For citation - Do cytowania

Shu, G., Yang, H., Chen, H., Zhang, Q., Tian, Y. (2015). Effect of incubation time, inoculum size, temperature, pasteurization time, goat milk powder and whey powder on ACE inhibitory activity in fermented milk by L. plantarum LP69. Acta Sci. Pol. Technol. Aliment., 14(2), 107-116. DOI: 10.17306/J.AFS.2015.2.12 